\title{
Trastorno por déficit de atención con hiperactividad y dependencia de sustancias depresoras. Una revisión
}

\section{Attention deficit hyperactivity disorder and Central Nervous System Depressants dependence. A review}

\author{
Constanza Dalgre*, **; Antonio Terán ${ }^{* * *}$; Vicente \\ García-VicenT ${ }^{\star \star * *}$; Carlos Roncero*, ${ }^{\star *}$
}

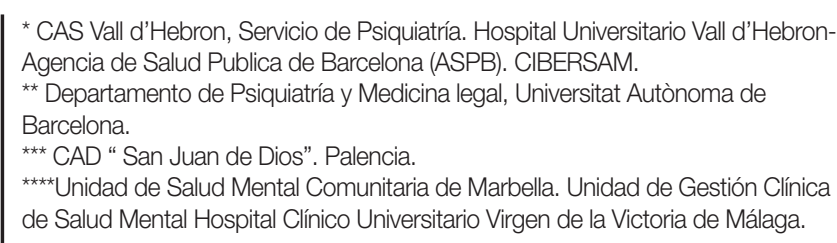

${ }^{*}$ CAS Vall d'Hebron, Servicio de Psiquiatría. Hospital Universitario Vall d'HebronAgencia de Salud Publica de Barcelona (ASPB). CIBERSAM.

*^ Departamento de Psiquiatría y Medicina legal, Universitat Autònoma de Barcelona.

*** CAD "San Juan de Dios". Palencia.

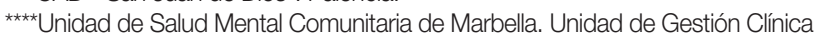
de Salud Mental Hospital Clínico Universitario Virgen de la Victoria de Málaga.

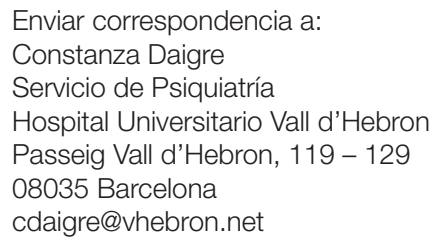

\section{Resumen}

Existe una elevada comorbilidad entre el trastorno por déficit de atención con hiperactividad (TDAH) y los trastornos por uso de sustancias. Se revisa la literatura sobre la prevalencia, características clínicas y tratamiento de la comorbilidad del TDAH con la dependencia de sustancias depresoras del SNC. Las prevalencias encontradas presentan amplia variabilidad (4,5\% a 58\%). El TDAH se asocia a una mayor gravedad de la adicción, menor edad de inicio del consumo y de la adicción, mayor presencia de otros trastornos psicopatológicos y mayor cronicidad. En pacientes drogodependientes el diagnóstico es un proceso complejo por el frecuente solapamiento de sintomas. Los instrumentos de cribado se deben utilizar con precaución. El tratamiento farmacológico ha mostrado eficacia en la reducción de los sintomas del TDAH y no hay consenso respecto a su influencia sobre el consumo. Sin embargo, los resultados se deben interpretar con cautela, porque las muestras son pequeñas. Las intervenciones psicoeducativas son relevantes, pero no se han descrito, ni estudiado sistemáticamente los resultados de este tipo de intervenciones. recibido: Mayo 2012 aceptado: Septiembre 2012

\section{Abstract}

The comorbidity between attention deficit hyperactivity disorder (ADHD) and substance use disorders is very common. A review of literature addressing prevalence, clinical features and treatment of the comorbidity between ADHD and CNS depressants was conducted. The prevalences found have a wide range (4.5\% to $58 \%$ ). ADHD has been associated with greater severity of addiction, early onset of consumption and addiction, more psychiatric comorbidity and more chronicity. In drug-dependent patients the diagnosis is a complex process because the frequent overlap of symptoms. The screening instruments should be used with caution. Drug therapy has shown efficacy in reducing ADHD symptoms, but there is no consensus regarding their influence on substance use. However, results should be interpreted cautiously, because the samples are small. Psychoeducational interventions are relevant, but treatment outcomes have not been described or studied systematically. 
E consumo de drogas y alcohol genera graves conflictos sociales y alta demanda de tratamiento en los sistemas sanitarios (Plan Nacional Sobre Drogas, 2009). Clínicamente las drogas se pueden clasificar según sus efectos sobre el sistema nervioso central (SNC) en depresores, estimulantes y alucinógenos (DSM-IV$T R$, 2000).s Dentro del grupo de las drogas depresoras se incluyen el alcohol, los hipnosedantes y los opiáceos. El cannabis presenta tanto efectos depresores como alucinógenos en el SNC (Bobes y Calafat, 2010), por lo cual es controversial su inclusión dentro del grupo de depresores. Sin embargo, se ha incluido en la presente revisión atendiendo a los efectos sedativos mencionados.

El trastorno por déficit de atención con hiperactividad (TDAH) es un trastorno del neurodesarrollo, predominantemente hereditario, de inicio en la infancia (DSM-IV-TR, 2000). Estudios longitudinales han demostrado que persiste entre el 50 y $65 \%$ de los casos hasta la edad adulta (Barkley, 1990; Biederman et al., 1996; Weiss, 1993). Las adicciones, así como el TDAH, se asocian a dificultades laborales e interpersonales, a un aumento de la criminalidad, a una mayor propensión a tener accidentes de tráfico y peor calidad de vida en general (Adler, 2008; Barkley, 2002; Bernfort, Nordfeldt y Persson, 2008; Biederman et al., 1993; Fischer, Barkley, Smallish y Fletcher, 2002; Goksøyr y Nøttestad, 2008; Harwood y Myers, 2004).

Los pacientes con TDAH tienen más riesgo de desarrollar drogodependencias y ésta tiende a cronificarse en comparación con el grupo de pacientes sin TDAH (Biederman, Wilens, Mick, Faraone y Spencer, 1998). Los niños con un TDAH no tratado tienen más riesgo de desarrollar una adicción que los niños sin este trastorno, tienden a iniciar precozmente el consumo de sustancias y pasan más rápidamente del uso, al abuso y a la dependencia de sustancias (Biederman et al., 1998). Además, un TDAH asociado a un trastorno por uso de sustancias, se asocia a una peor evolución y a un pronóstico menos favorable de la drogodependencia (Arias et al., 2008; Biederman et al., 1998; Brooner, King, Kidorf, Schmidt y Bigelow, 1997; Charach, Yeung, Climans y Lillie, 2011; Szobot et al., 2008; Wilens, Biederman, Mick, Faraone y Spencer, 1997; Wilens, Biederman y Mick, 1998).

Kollins (2008) en una revisión ha planteado que en personas con un TDAH, la comorbilidad con el trastorno disocial, trastorno oposicionista desafiante, trastorno bipolar y trastorno de la conducta alimentaria aumentan el riesgo del desarrollo de un trastornos por uso de sustancias. Además, se ha descrito que entre los factores sociodemográficos, un bajo nivel socioeconómico y el fracaso escolar también pueden aumentar el riesgo de un TUS (Kollins, 2008).

Debido a la frecuencia del consumo de sustancias depresoras del SNC y a la escasez de revisiones específicas, se pretende realizar una actualización sobre la prevalencia, características clínicas y tratamiento de la asociación entre el TDAH y consumo de sustancias depresoras.

\section{Metodología}

Se realizó una búsqueda de la literatura en las principales bases de datos entre 1990 y 2011. Los criterios de búsqueda y de inclusión en el presente artículo se encuentran detallados en la figura 1.
$\mathrm{D}$ rug and alcohol use generates serious social conflict and high demand for treatment in health systems (National Plan on Drugs, 2009). Clinically, drugs may be classified according to their effects on the central nervous system (CNS) as depressants, stimulants, and hallucinogens (DSM-IV-TR, 2000).s Within the group of depressant drugs are included alcohol, hypnosedatives and opioids. Cannabis shows both depressant and hallucinogenic effects on the CNS (Bobes and Calafat, 2010), so its inclusion in the depressants group is controversial. However, it has been included in this review based on the above-mentioned sedative effects.

Attention deficit hyperactivity disorder (ADHD) is a neurodevelopmental disorder, predominantly hereditary, starting in childhood (DSM-IV-TR, 2000). Longitudinal studies have shown that it persists in 50 to $65 \%$ of cases to adulthood (Barkley, 1990; Biederman et al., 1996; Weiss, 1993). Addictions, as well as ADHD, are associated with occupational and interpersonal difficulties, increased crime, a greater propensity to have traffic accidents and poorer quality of life in general (Adler, 2008; Barkley, 2002; Bernfort, Nordfeldt, \& Persson, 2008; Biederman et al., 1993; Fischer, Barkley, Smallish, \& Fletcher, 2002; Goksøyr \& Nøttestad, 2008; Harwood \& Myers, 2004).

Patients with ADHD have greater risk of developing drug addictions and this usually become chronic compared to patients without ADHD (Biederman, Wilens, Mick, Faraone, \& Spencer, 1998). Children with an untreated ADHD have greater risk of developing addiction than children without this disorder, usually starting substance abuse early and moving faster from use to abuse and to substance dependence (Biederman et al., 1998). In addition, an ADHD associated with a substance abuse disorder is associated with a poorer course and a less favorable prognosis of drug abuse (Arias et al., 2008; Biederman et al., 1998; Brooner, King, Kidorf, Schmidt, \& Bigelow, 1997; Charach, Yeung, Climans, \& Lillie, 2011; Szobot et al., 2008; Wilens, Biederman, Mick, Faraone, \& Spencer, 1997; Wilens, Biederman, \& Mick, 1998).

Kollins (2008) proposed in a review that in persons with ADHD, comorbidity with antisocial disorder, oppositional defiant disorder, bipolar disorder, and eating disorder increases the risk of development of a substance use disorder. In addition, it has been reported that among sociodemographic factors, a low socioeconomic level and school failure may also increase the risk of a substance use disorder (Kollins, 2008).

Due to the frequency of consumption of CNS depressant substances and few specific reviews, our aim was to conduct an update on the prevalence, clinical characteristics and treatment of the association between ADHD and depressant substance use.

\section{Methods}

A literature search was performed in the main databases for articles published between 1990 and 2011. The search and inclusion criteria used in this article are detailed in Figure 1. 
Figura 1. Procedimiento de búsqueda e incorporación de los estudios

Figure 1. Procedure for literature search and inclusion of studies

\begin{tabular}{|c|c|}
\hline $\begin{array}{l}139 \text { Artículos Seleccionados } \\
139 \text { Articles Selected }\end{array}$ & $\begin{array}{l}\text { Criterios de selección: } \\
\text { - Disponible en Medline, Web of Science, Journal Citation Reports } \\
\text { - Entre } 1990 \text { y } 2011 \\
\text { - Palabras clave: ADHD, attention deficit/hyperactivity disorder, substance use disorder, addiction, } \\
\text { dependence, abuse, alcohol, cannabis, marihuana, hypnosdative, sedative, diazepam, opiates, heroin, } \\
\text { - Inethadone, psychostimulants, methylphenidate y atomoxetine. } \\
\text { - } \text { Publés o Castellano } \\
\text { Selection criterianes periódicas } \\
\text { - Available in Medline, Web of Science, Journal Citation Reports } \\
\text { - Between } 1990 \text { and } 2011 \\
\text { - Key words: ADHD, attention deficithyperactivity disorder, substance use disorder, addiction, abuse, } \\
\text { abuse, alcohol, cannabis, marihuana, hypnosedative, sedative, diazepam, opiates, heroin, methadone, } \\
\text { - } \text { psychostimulants, methylphenidate and atomoxetine. } \\
\text { - English or Spanish }\end{array}$ \\
\hline$\downarrow$ & \\
\hline $\begin{array}{l}88 \text { Artículos y Documentos } \\
\text { Incluidos } \\
88 \text { Articles and Documents } \\
\text { Included }\end{array}$ & $\begin{array}{l}\text { Criterios de inclusión: } \\
\text { Incluir información relacionada con: epidemiologia, caracteristicas clinicas, diagnóstico, tratamiento farma- } \\
\text { cológico y psicosocial. } \\
\text { Inclusion criteria: } \\
\text { Include information related to: } \\
\text { epidemiology, clinical characteristics, diagnosis, drug and psychosocial treatment. }\end{array}$ \\
\hline
\end{tabular}

\section{Resultados}

\section{Epidemiología de las adicciones a sustancias depresoras del SNC}

Los resultados de la encuesta domiciliaria sobre alcohol y drogas en España (2009), indican que las sustancias más frecuentemente consumidas por la población entre 15 y 64 años son el alcohol y el tabaco, seguidas del cannabis e hipnosedantes. También se señala que las drogas que se perciben como más peligrosas son la heroína y la cocaína. Respecto a la prevalencia de consumo, adicción y tendencias epidemiológicas de las sustancias depresoras del SNC, se conoce lo siguiente (Plan Nacional Sobre Drogas, 2009).

- Alcohol. La prevalencia de consumo de bebidas alcohólicas alguna vez en la vida es de $88 \%$ y la prevalencia de consumo diario es de $10.2 \%$.

- Cannabis. es la droga ilegal más consumida en España. El $27.3 \%$ de la población estudiada ha consumido alguna vez en la vida y el 1.5\% consume diariamente.

- Hipnosedantes. En la gran mayoría de los casos, los hipnosedantes consumidos son benzodiazepinas. La tendencia de la prevalencia del consumo va en aumento. Actualmente el $6 \%$ de la población estudiada ha consumido alguna vez en la vida y el $1.1 \%$ consume diariamente.

- Heroína. Hasta el 2004 todos los indicadores mostraban una tendencia descendente del consumo de heroí-

\section{Results}

\section{Epidemiology of addictions to CNS depressant substances}

The results of the home survey on alcohol and drugs in Spain (2009) suggest that the substances most commonly used by the population between 15 and 64 years of age are alcohol and tobacco, followed by cannabis and hypnosedatives. It is also noted that the drugs perceived as most dangerous are heroin and cocaine. Regarding the prevalence of consumption, addiction and epidemiological trends of CNS depressant substances, the following is known (National Plan on Drugs, 2009).

- Alcohol. The prevalence of consumption of alcoholic drinks ever in life is $88 \%$ and the prevalence of daily intake is $10.2 \%$

- Cannabis. It is the most commonly consumed illegal drug in Spain. Over a quarter $(27.3 \%)$ of the population studied have consumed it at some time in their life and $1.5 \%$ consume it daily.

- Hypnosedatives. In the vast majority of cases, the hypnosedatives consumed are benzodiazepines. The trend in prevalence of consumption is increasing. Currently, $6 \%$ of the population studied have consumed them at some time in their lives and 1.1\% consume them daily. 
na. Pero desde 2006 se ha detectado cierto aumento de la prevalencia de consumo de heroína alguna vez en la vida, del número de primeras admisiones a tratamiento por abuso o dependencia. Los últimos resultados indican que $0.8 \%$ ha consumido alguna vez en la vida.

\section{Epidemiología del TDAH en drogodependientes}

En población general adulta se ha estimado una prevalencia de TDAH del 1.2 al 7.3\% (Fayyad et al., 2007; Kessler, Chiu, Demler, Merikangas y Walters, 2005). En pacientes en tratamiento por trastornos por uso de sustancias (TUS) se han encontrado mayores prevalencias de TDAH, que habitualmente se sitúan alrededor del 20\% en función de las muestras estudiadas y los instrumentos utilizados (Arias et al., 2008; Clure et al., 1999; Daigre et al., 2009; Daigre et al., 2012; Kessler et al., 2006; Perez de Los Cobos et al., 2010; Wilens y Dodson, 2004). En un reciente metanálisis, que incluyó 29 estudios, se ha estimado la prevalencia del TDAH en TUS en un 23.1\% (van Emmerik-van Oortmerssen et al., 2011).

Las personas con TDAH consumen las mismas drogas que la población general, pero en mayores cantidades. Las sustancias depresoras como el alcohol y el cannabis son las sustancias más consumidas, después del tabaco (Kessler et al., 2006; Sullivan y Rudnik-Levin, 2001).

\section{TDAH y consumo de sustancias depresoras}

Alcohol. Las prevalencias de TDAH en el adulto en dependientes de alcohol son del 21 al 23\% (Johann, Bobbe, Putzhammer y Wodarz, 2003; Ohlmeier, Peters, Te Wildt, Zedler, Ziegenbein, Wiese, Emrich y Schneider, 2008). Inversamente las prevalencias de abuso y dependencia de alcohol en adultos con TDAH varían del 17 al 45\% (Biederman, et al., 1998; Faraone, Wilens, Petty, Antshel, Spencer y Biederman, 2007).

Lee et al. (2011) han publicado un metanálisis que incluyó 27 estudios longitudinales, sobre la asociación entre la presencia de un TDAH y el desarrollo de TUS, describen que la presencia de un TDAH en la infancia no aumenta la probabilidad de haber consumido alcohol. Lo cual es esperable, ya que el consumo de alcohol es normativo dentro de la población adulta joven. Sin embargo, se señala que los antecedentes de TDAH en la infancia aumentan el riesgo de desarrollar abuso o dependencia de alcohol en 1.74 veces (Lee, Humphreys, Flory, Liu y Glass, 2011). Otra revisión sistemática reciente llega a la misma conclusión, los antecedentes de TDAH en la infancia se asocian a trastornos por consumo de alcohol en los primeros años de la etapa adulta $(O R=1.35)$ (Charach, Yeung, Climans y Lillie, 2011) (Tabla 1).

EI TDAH se asocia a un inicio precoz de la adicción. En este sentido, en una muestra de 1269 niños se ha identificado que los factores de riesgo en la progresión desde el uso a
- Heroin. Until 2004 all indicators showed a downward trend in heroin consumption. However, since 2006, a certain increase has been detected in prevalence of heroin consumption ever in life, and number of first admissions to treatment for dependence or abuse. The latest results indicate that $0.8 \%$ has consumed it at some time in their life.

\section{Epidemiology of ADHD in drug addicts}

In the general adult population, a prevalence of ADHD of 1.2 to $7.3 \%$ has been estimated (Fayyad et al., 2007; Kessler, Chiu, Demler, Merikangas, \& Walters, 2005). Higher prevalences of ADHD have been found in patients treated for substance use disorders (SUDs), which are usually around $20 \%$ depending on the samples studied and the instruments used (Arias et al., 2008; Clure et al., 1999; Daigre et al., 2009; Daigre et al., 2012; Kessler et al., 2006; Perez de Los Cobos et al., 2010; Wilens \& Dodson, 2004). In a recent meta-analysis including 29 studies, a prevalence of ADHD in SUD of 23.1\% was estimated (van Emmerik-van Oortmerssen et al., 2011).

People with ADHD consume the same drugs as the general population, but in greater amounts. Depressant substances such as alcohol and cannabis are the most widely consumed substances, after tobacco (Kessler et al., 2006; Sullivan \& Rudnik-Levin, 2001).

\section{ADHD and depressant substance use}

Alcohol. Prevalences of ADHD in alcohol dependent adults are from 21 to 23\% (Johann, Bobbe, Putzhammer \& Wodarz, 2003; Ohlmeier, Peters, You Wildt, Zedler, Ziegenbein, Wiese, Emrich \& Schneider, 2008). Conversely, prevalences of alcohol abuse and dependence in adults with ADHD range from 17 to 45\% (Biederman, et al., 1998; Faraone, Wilens, Petty, Antshel, Spencer \& Biederman, 2007).

Lee et al. (2011) published a meta-analysis including 27 longitudinal studies on the association between the presence of ADHD and development of the SUD, reporting that the presence of an ADHD in childhood does not increase the probability of having consumed alcohol. This was to be expected, since alcohol consumption is required behavior among young adults. However, it is noted that a history of ADHD in childhood increases by 1.74 times the risk of developing alcohol abuse or dependence (Lee, Humphreys, Flory, Liu, \& Glass, 2011). Another recent systematic review reaches the same conclusion, a history of ADHD in childhood is associated with alcohol use disorders in the first years of adulthood $(O R=1.35)$ (Charach, Yeung, Climans, \& Lillie, 2011) (Table 1).

ADHD is associated with an early onset of addiction. In this regard, the risk factors identified in a sample of 1269 children for progression from alcohol use to dependence are nicotine dependency, cannabis abuse and generalized anxiety disorder. 
la dependencia de alcohol, son la dependencia de nicotina, el abuso de cannabis y el trastorno de ansiedad generalizada. De esta manera se enfatiza el rol de la comorbilidad psiquiátrica y de otros TUS, como factores de riesgo determinantes para el desarrollo de dependencia del alcohol (Sartor, Lynskey, Heath, Jacob y True, 2007). En otros dos estudios se ha descrito también que los pacientes dependientes de alcohol que presentan un TDAH comórbido, se caracterizan por el inicio precoz de la adicción (Ercan, Coskunol, Varan y Toksoz, 2003; Sartor, Lynskey, Heath, Jacob y True, 2007; Sringeri, Rajkumar, Muralidharan, Chandrashekar y Benegal, 2008). Esto tendría repercusiones en el tratamiento, ya que el inicio precoz se ha asociado a mayor gravedad de la adicción, antecedentes familiares, problemas conductuales en la infancia, mayor craving, hostilidad, rasgos de personalidad antisocial, trastornos del estado de ánimo y a un ajuste social más pobre, que los pacientes que desarrollan la dependencia posteriormente (Sringeri, Rajkumar, Muralidharan, Chandrashekar y Benegal, 2008).

A pesar de que los tres estudios previamente citados describen un inicio precoz del alcoholismo asociado a un TDAH, Tuithof et al. (2011) rechazan esta asociación, aunque sí encuentran que el TDAH se asocia significativamente a mayor prevalencia de consumo, abuso y dependencia del alcohol (Tabla 1).

El rol del trastorno disocial en esta asociación es de gran interés, ya que se ha descrito que actúa como mediador entre el TDAH y los trastornos por consumo de alcohol, de manera que se desarrollaría primero un TDAH, posteriormente un trastorno disocial y finalmente un abuso de alcohol. De esta manera un tratamiento del TDAH podría prevenir el desarrollo de trastorno disocial y adicción al alcohol (Sartor et al., 2007; Tuithof, Ten Have, van den Brink, Vollebergh y de Graaf, 2011).

Respecto a la evolución en el tratamiento, se ha descrito que pacientes dependientes de alcohol que también presentaban TDAH recaían una media de 2.7 meses antes que los pacientes sin este trastorno (Ercan, et al., 2003; Grella, Hser, Joshi y Rounds-Bryant, 2001) (Tabla 1).

Se ha sugerido la automedicación como hipótesis explicativa de esta comorbilidad, por ello en estos pacientes es de gran importancia del diagnóstico precoz y tratamiento adecuado de ambos trastornos, con el fin de prevenir el empeoramiento de la adicción (Ohlmeier et al., 2007).
In this way, it is emphasized that psychiatric comorbidity and other SUDs play an important role as determining risk factors for the development of alcohol dependence (Sartor, Lynskey, Heath, Jacob, \& True, 2007). In another two studies, it has also been reported that alcohol dependent patients who have a comorbid ADHD are characterized by early initiation of addiction (Ercan, Coskunol, Varan, \& Toksoz, 2003; Sartor, Lynskey, Heath, Jacob, \& True, 2007; Sringeri, Rajkumar, Muralidharan, Chandrashekar, \& Benegal, 2008). This would affect treatment, since early initiation has been associated with more severe addiction, family history, behavioural problems in childhood, greater craving, hostility, antisocial personality traits, mood disorders and poorer social adjustment than patients who develop dependence later (Sringeri, Rajkumar, Muralidharan, Chandrashekar, \& Benegal, 2008).

Although the three above studies describe an early onset of alcoholism associated with a ADHD, Tuithof et al. (2011) rejected this association, but found that ADHD is significantly associated with a greater prevalence of alcohol use, abuse and dependence (Table 1).

The role of antisocial disorder in this association is of great interest, since it has been reported that it acts as a mediator between ADHD and alcohol use disorders, so that first an ADHD would develop, then an antisocial disorder, and finally alcohol abuse. Thus, treatment of ADHD may prevent the development of antisocial disorder and alcohol addiction (Sartor et al., 2007; Tuithof, Ten Have, van den Brink, Vollebergh, \& de Graaf, 2011).

With regard to the clinical course during treatment, it has been reported that alcohol dependent patients who also had ADHD relapsed an average of 2.7 months before patients without this disorder (Ercan, et al., 2003; Grella, Hser, Joshi, \& Rounds-Bryant, 2001) (Table 1).

Self-medication has been suggested as an explanatory hypothesis for this comorbidity, so that early diagnosis and appropriate treatment of both disorders in these patients is of great importance to prevent worsening of addiction (Ohlmeier et al., 2007).

Tabla 1. Características clínicas de pacientes dependientes de alcohol con un TDAH comórbido Table 1. Clinical characteristics of alcohol-dependent patients with a comorbid ADHD

El TDAH aumenta el riesgo de dependencia de alcohol en 1.35 a 1.74 veces. ADHD increases the risk of alcohol dependence by 1.35 to 1.74 times.

Los pacientes dependientes de alcohol con TDAH presentan mayor prevalencia de dependencia de nicotina Alcohol-dependent patients with ADHD show a higher prevalence of nicotine dependence.

Tres estudios indican que el TDAH se asocia a inicio precoz de la adicción al alcohol. Un estudio desestima esta asociación Three studies suggest that ADHD is associated with early onset of alcohol addiction. One study rejects this association.

El trastorno disocial en la infancia actuaría como mediador o un trastorno que se desarrollaria entre TDAH y alcoholismo Antisocial disorder in childhood would act as mediator or a disorder that would develop between ADHD and alcoholism.

Los pacientes dependientes de alcohol con TDAH recaen antes en el tratamiento

Alcohol dependent patients with ADHD relapse earlier during treatment. 
Cannabis. La prevalencia del TDAH en dependientes de cannabis, no está suficientemente aclarada, existen pocos estudios publicados sobre este aspecto, en ellos se sitúa entre el $40 \%$ y 58\% (Tims et al., 2002; Grella, Hser, Joshi y RoundsBryant, 2001). Al igual que en población general, el cannabis es la sustancia ilegal consumida con mayor frecuencia (67\%) por los pacientes con TDAH (Sullivan y Rudnik-Levin, 2001). Se conoce que el consumo de cannabis se asocia a más problemas de salud mental en general (Fergusson y Boden, 2008). Específicamente se ha descrito la asociación entre el consumo de cannabis y problemas que podrían solaparse con los del TDAH, como son las dificultades de atención, incluyendo un peor desempeño en las tareas que requieren atención, memoria de trabajo, velocidad del procesamiento de la información y dificultades en las funciones ejecutivas (Ehrenreich et al., 1999; Harvey, Sellman, Porter y Frampton, 2007; Kalant, 2004; Lundqvist, 2005; Solowij et al., 2002) .

En un estudio metanalítico se describió que la presencia de un TDAH infantil aumenta en 2.78 veces el riesgo de desarroIlar dependencia de cannabis (Lee et al., 2011). En otro sentido, Fergusson y Boden (2008) examinaron la relación entre el consumo de cannabis en la adolescencia y en la adultez joven con los síntomas de TDAH en la edad adulta. Estudiaron una gran cohorte de 1265 personas, a quienes realizaron un seguimiento durante 25 años. Describen que el aumento del consumo de cannabis se asocia a un aumento de los sintomas de TDAH. Además, esta asociación no se explica por variables sociodemográficas, familiares, cognitiva y conductuales, ya que sus posibles efectos de confusión fueron descartados. Asimismo, encuentran que la relación entre el consumo de cannabis y los síntomas de TDAH está mediada por el consumo de otras drogas, lo cual sugiere una posible relación, en que el consumo de cannabis incrementa el consumo de otras drogas, lo que a su vez, se asocia al incremento de los síntomas de TDAH.

Opiáceo. La prevalencia del TDAH en pacientes dependientes de opiáceos ha sido menos estudiada, en comparación con dependientes de otras sustancias. Además, algunos estudios sólo estudian los antecedentes de TDAH en la infancia, sin incluir la sintomatología en la vida adulta (Davids et al., 2005; Modestin, Matutat y Wurmle, 2001). No se conoce una estimación clara de la prevalencia de TDAH en el adulto en dependientes de opiáceos, variando entre 4.5 y $24.9 \%$ (Arias et al., 2008; Carpentier, van Gogh, Knapen, Buitelaar y De Jong, 2010; King, Brooner, Kidorf, Stoller y Mirsky, 1999; Kolpe y Carlson, 2007).

Los pacientes dependientes de opiáceos con un TDAH comórbido presentan una tendencia a presentar mayor gravedad de la adicción, mayor comorbilidad psiquiátrica en general tanto del eje I como del eje II, especialmente más prevalencia de trastorno de la personalidad antisocial, más comorbilidad con otros trastornos por uso de sustancias, inicio más precoz del consumo y del desarrollo de abuso de sustancias (Carpentier, et al., 2010).

Al comparar las caracteristicas clínicas de pacientes dependientes de opiáceos se ha observado que los pacientes con un TDAH presentan mayor probabilidad de ser incorporados a un tratamiento sustitutivo con opioides. Este hecho se podría asociar con una mayor gravedad, ya que los pacientes dependientes de opiáceos, a quienes se les incluye en un programa
Cannabis. The prevalence of ADHD in cannabis dependent patients has not been adequately clarified, because there are few studies, where it ranged from 40 to $58 \%$ (Tims et al., 2002; Grella, Hser, Joshi, \& Rounds-Bryant, 2001). As in the general population, cannabis is the most frequently taken illegal substance (67\%) by patients with ADHD (Sullivan \& RudnikLevin, 2001). It is known that cannabis use is associated with more mental health problems in general (Fergusson \& Boden, 2008). Specifically, an association has been reported between cannabis use and problems that may overlap with those of ADHD, such as attention difficulties, including poorer performance in attention-requiring tasks, working memory, information processing speed and difficulties in executive functions (Ehrenreich et al., 1999; Harvey, Sellman, Porter, \& Frampton, 2007; Kalant, 2004; Lundqvist, 2005; Solowij et al., 2002) .

In a meta-analysis study, it was reported that the presence of a childhood ADHD increased 2.78 times the risk of developing cannabis dependence (Lee et al., 2011). On the other hand, Fergusson and Boden (2008) examined the relationship between cannabis use in adolescence and young adulthood and symptoms of ADHD in adulthood. They studied a large cohort of 1265 people who they followed for 25 years. They reported that increased cannabis use is associated with increased symptoms of ADHD. In addition, this association is not explained by sociodemographic, familial, cognitive or behavioral variables, since their possible confounding effects were excluded. They also found that the relationship between cannabis use and symptoms of ADHD is mediated by use of other drugs, thus suggesting a possible relationship where cannabis use increases use of other drugs which in turn is associated with increased symptoms of ADHD.

Opioids. The prevalence of ADHD in opioid-dependent patients has been less studied as compared to patients dependent on other substances. In addition, some studies only examined a history of ADHD in childhood, without including symptoms in adulthood (Davids et al., 2005; Modestin, Matutat, \& Wurmle, 2001). A clear estimate of the prevalence of ADHD in opioid-dependent adults is not known, ranging from 4.5 to 24.9\% (Arias et al., 2008; Carpentier, van Gogh, Knapen, Buitelaar, \& De Jong, 2010; King, Brooner, Kidorf, Stoller, \& Mirsky, 1999; Kolpe \& Carlson, 2007).

Opioid-dependent patients with a comorbid ADHD show a tendency to have more severe addiction, greater psychiatric comorbidity in general of both axis I and axis II, particularly greater prevalence of antisocial personality disorder, more comorbidity with other substance use disorders, and earlier onset of use and development of substance abuse (Carpentier, et al., 2010).

On comparing the clinical characteristics of opioidpendent patients, it was observed that patients with ADHD are more likely to be entered into opioid replacement therapy. This could be associated with greater severity, because opioid-dependent patients who are included in a methadone maintenance program (MMP) are usually chronic patients who have been included several times in these programs 
de mantenimiento con metadona (PMM), suelen ser pacientes crónicos, que han sido incluidos varias veces en estos programas (Roncero et al., 2011) y que presentan una elevada gravedad de la dependencia (Subramaniam y Stitzer, 2009).

Se ha estudiado la asociación entre los síntomas de TDAH y los resultados de un PMM, centrado en favorecer la abstinencia. EI TDAH fue evaluado mediante una prueba de cribado al inicio del programa. Se ha encontró que los pacientes con síntomas de TDAH, al cabo de nueve meses de tratamiento habian logrado reducir en menor medida el consumo de sustancias y tenían significativamente menos probabilidad de haber alcanzado la abstinencia (Kolpe y Carlson, 2007). Lo cual sugiere un peor pronóstico de la adicción. (Tabla 2).
(Roncero et al., 2011) and have high severity of dependence (Subramaniam \& Stitzer, 2009).

The association has been studied between symptoms of ADHD and the results of a MMP aimed at promoting abstinence. ADHD was assessed by a screening test at the start of the program. It was found that patients with symptoms of ADHD after 9 months of treatment had been able to reduce substance use to a lesser extent and were significantly less likely to have achieved abstinence (Kolpe \& Carlson, 2007). Which suggests a poorer prognosis of addiction. (Table 2).

Tabla 2. Características clínicas de pacientes dependientes de opiáceos con un TDAH comórbido Table 2. Clinical characteristics of opioid- dependent patients with a comorbid ADHD

\begin{tabular}{l}
\hline Alta variabilidad de las prevalencias encontradas ( $4.5 \%$ a $24.9 \%)$. \\
High variability of reported prevalences ( $4.5 \%$ to $24.9 \%)$. \\
\hline Mayor prevalencia de otros TUS. \\
Greater prevalence of other SUDs. \\
\hline Más frecuencia de inclusión en PMM. \\
Higher frequency of inclusion in MMP. \\
\hline Mayor prevalencia de trastorno de personalidad antisocial. \\
Higher prevalence of antisocial personality disorder. \\
\hline Inicio precoz del consumo y de la dependencia. \\
Early onset of use and dependence. \\
\hline El TDAH se asocia a más recaidas. \\
ADHD is associated with more relapses. \\
\hline El tratamiento combinado con estimulantes y metadona se ha asociado a reducción de \\
síntomas de TDAH y del consumo.Combined treatment with stimulants and methadone \\
has been associated with a reduction in ADHD symptoms and drug use.
\end{tabular}

Hipnosedantes. Después de haber realizado una búsqueda bibliográfica exhaustiva no se han encontrado referencias de estudios que analicen el uso de hipnosedantes en pacientes con TDAH. A pesar de ello, considerando el mayor riesgo para el desarrollo de adicciones en general, y la alta prevalencia de trastornos del sueño (alrededor del 50\% en niños (Corkum, Davidson y Macpherson, 2011; Hoban, 2004) y trastornos de ansiedad (Barkley, 2002) en pacientes con TDAH, es posible hipotetizar que las personas con TDAH tiendan a presentar más abuso de hipnosedantes. Sin embargo, esta idea debe ser contrastada, mediante estudios diseñados específicamente para ello.

\section{Diagnóstico}

El diagnóstico del TDAH en la vida adulta es un proceso complejo y aún más en pacientes dependientes de sustancias. Dentro de las dificultades a las que se enfrentan los clínicos está el frecuente solapamiento de los síntomas del TDAH con los de la intoxicación y/o abstinencia y la necesidad de hacer un diagnóstico retrospectivo de los sintomas de la infancia. Además, es necesario adaptar los criterios diagnósticos del DSM, ya que actualmente están diseñados especialmente
Hypnosedatives. After completed a comprehensive literature search, no references to studies analyzing use of hypnosedatives in patients with ADHD were found. Despite this, considering the greater risk for the development of addictions in general, and the high prevalence of sleep disturbances (around 50\% in children (Corkum, Davidson, \& Macpherson, 2011; Hoban, 2004)) and anxiety disorders (Barkley, 2002) in patients with $A D H D$, it can be hypothesized that people with ADHD tend to show more abuse of hypnosedatives. However, this idea must be confirmed by studies designed specifically for this purpose.

\section{Diagnosis}

The diagnosis of ADHD in adulthood is a complex process and even more so in substance dependent patients. Among the difficulties clinicians face is the frequent overlapping of ADHD symptoms with intoxication and/or withdrawal symptoms and the need to perform a retrospective diagnosis of symptoms from childhood. In addition, DSM diagnostic criteria need to be adapted since they are currently designed especially for children, but diagnosis in adulthood is permitted 
para niños, aunque se permite el diagnóstico en la edad adulta desde 1980 (DSM-III). Debido a estas dificultades es posible que en pacientes en tratamiento por TUS, se pueda producir un sobrediagnóstico o un infradiagnóstico del TDAH. En el proceso diagnóstico se ha descrito cómo los propios adultos con TDAH son los mejores informantes de sus sintomas. Sin embargo, es relevante la información complementaria aportada por padres, hermanos mayores o pareja (Kooij et al., 2008). El proceso diagnóstico consiste en una evaluación sistemática de los síntomas de TDAH a lo largo de la vida. Es crítico evaluar la edad de inicio de los síntomas, junto con la generalización a diferentes ámbitos y el deterioro clínico. A pesar de que la comorbilidad en el TDAH es la norma más que la excepción, se debe descartar que los síntomas de inatención, hiperactividad e impulsividad en los pacientes adictos no se deben a otros trastornos mentales.

El diagnóstico es clínico, sin embargo, existen cuestionarios y entrevistas que pueden contribuir a la orientación diagnóstica. Dentro de estas herramientas, los cuestionarios de cribado son de gran utilidad para la identificación de casos, aunque suelen presentarse más falsos positivos que en muestras sin TUS. En el contexto español, se cuenta con el cuestionario Wender Utah Rating Scale (WURS), que evalúa TDAH en la infancia de manera retrospectiva, éste ha sido adaptado en una muestra de pacientes en tratamiento por dependencia de alcohol, de tabaco y ludopatía, mostrando adecuadas propiedades psicométricas. Se eligieron los 25 ítems que mejor discriminaban los casos de los controles. El coeficiente de Cronbach para esta subescala fue de 0,94. El punto de corte de 32 que presentaba una sensibilidad (91,5\%) y especificidad (90,8\%). Los valores predictivos positivo y negativo fueron 81 y $96 \%$, respectivamente (Rodriguez-Jimenez et al., 2001). Para evaluar los sintomas en la adultez, se ha estudiado el cuestionario Adult ADHD Self-Report Scale (ASRS-v1.1) en pacientes en tratamiento por uso de sustancias. El ASRS con punto de corte 4 en las seis primeras preguntas, presenta una sensibilidad del $87,5 \%$ y una especificidad del 68,8\% (Daigre et al., 2009). Otro estudio español, también ha encontrado adecuadas características psicométricas para este instrumento (Pedrero Perez y Puerta Garcia, 2007). En pacientes dependientes de cocaína, se ha obsevado que las puntuaciones medias obtenidas en el cuestionario Current Behavior Scale Self-Report de Barkley son significativamente superiores en los pacientes con TDAH (Vergara et al., 2010).

Además, existen otros cuestionarios, que aunque sus características psicométricas no han sido estudiadas especificamente en drogodependientes, pueden aportar información relevante al clínico sobre el diagnostico de TADH en adultos. Dentro de estos se encuentra la Escala de Autoevaluación del TDAH en Adultos, compuesta por 18 items que siguen criterios del DSM-IV-TR y que ha sido adaptada al español (Bosch et al., 2009). También se encuentra la Escala de Conners para la evaluación de TDAH del Adulto (CAARS - Autoinforme: versión larga). Esta se compone de 66 ítems que entregan información sobre síntomas relacionados con la atención, hiperactividad, impulsividad y autoestima. (La Malfa, Lassi, Bertelli, Pallanti y Albertini, 2008). since 1980 (DSM-III). Due to these difficulties, it is likely that overdiagnosis or underdiagnosis of ADHD may occur in patients treated for SUD. It has been reported that adults with ADHD are the best informers of their symptoms in the diagnostic process. However, supplemental information provided by parents, older siblings, or partner is also relevant (Kooij et al., 2008). The diagnostic process consists of a systematic evaluation of symptoms of ADHD over the patient's lifetime. It is critical to evaluate the age at onset of the symptoms, together with the generalization to different areas and clinical impairment. Although comorbidity in ADHD is more the rule than the exception, it must be excluded that symptoms of inattention, hyperactivity and impulsivity in addict patients are not due to other mental disorders.

The diagnosis is clinical, however, there are questionnaires and interviews that may aid in the diagnostic approach. Among these tools, screening questionnaires are very useful for identifying cases, though they usually show more false positives than in samples without SUDs. In Spain, the Wender Utah Rating Scale (WURS) questionnaire is available, which assesses childhood ADHD and has been adapted in a sample of patients treated for alcohol dependence, smoking and compulsive gambling, showing adequate psychometric properties. The 25 items best discriminating cases from controls were selected. The Cronbach's coefficient for this subscale was 0.94 . The cutoff point of 32 showed a sensitivity of $91.5 \%$ and a specificity of $90.8 \%$. Positive and negative predictive values were $81 \%$ and $96 \%$, respectively (RodriguezJimenez et al., 2001). To evaluate symptoms in adulthood, the Adult ADHD Self-Report Scale (ASRS-v1.1) questionnaire was studied in patients treated for substance use. The ASRS with a cutoff point of 4 in the first six questions has a sensitivity of $87.5 \%$ and a specificity of $68.8 \%$ (Daigre et al., 2009). Another Spanish study has also found adequate psychometric characteristics for this instrument (Pedrero Perez \& Puerta Garcia, 2007). In cocaine-dependent patients, it was observed that the mean scores obtained in Barkley's Current Behaviour Scale Self-Report were significantly higher in patients with ADHD (Vergara et al., 2010).

In addition, there are other questionnaires which, although their psychometric characteristics have not been specifically studied in drug addicts, could provide relevant information to the clinician on diagnosis of ADHD in adults. Among these is the Adult ADHD Self-Assessment Scale, consisting of 18 items that follow the criteria of DSM-IV-TR and have been adapted to Spanish (Bosch et al., 2009). Conners' Scale is also found for the assessment of ADHD in adults (CAARS-Self-Report: long version). This includes 66 items that give information on symptoms related to attention, hyperactivity, impulsiveness, and self-esteem. (La Malfa, Lassi, Bertelli, Pallanti and Albertini, 2008).

Of note within structured interviews is Conners' Adult ADHD Diagnostic Interview for DSM-IV (CAADID), which evaluates both childhood and adulthood symptoms according 
Dentro de las entrevistas semiestructuradas destaca la Conners' Adult ADHD Diagnostic Interview for DSM-IV (CAADID), que evalúa síntomas tanto de la niñez como la etapa adulta, siguiendo criterios DSM-IV, de manera que permite hacer un diagnóstico retrospectivo del TDAH en la infancia además del de la vida adulta. La versión española estudiada en pacientes con TDAH ha mostrado buenas propiedades psicométricas, con una sensibilidad de $98.86 \%(95 \% \mathrm{Cl}$, $97.41 \%-99.54 \%)$ y una especificidad de $67.68 \%(95 \% \mathrm{Cl}$, $59.88 \%-74.65 \%$ ) e índice kappa de 0.74 entre la CAADID II y el diagnóstico clínico (Ramos-Quiroga, Bosch, Richarte, Valero, Gomez-Barros, Nogueira... Casas, 2012). Otra entrevista semiestructurada es la Psychiatry Research Interview for Substance and Mental Disorders (PRISM), está basada en los criterios del DSM-IV y ha sido diseñada específicamente para estudiar la comorbilidad en pacientes con trastornos por uso de sustancias (Hasin, Samet, Nunes, Meydan, Matseoane y Waxman, 2006). Se ha integrado y estudiado la validez del modulo que evalúa el TDAH a lo largo de la vida, siendo buenas las propiedades psicométricas (sensibilidad 90\% y especificidad 87.5\%) (Ramos-Quiroga, Díaz-Digon, Comín, Bosch, Palomar, Chalita y Casas, 2012).

\section{Tratamiento Farmacológico}

Son pocos los estudios que abordan el tratamiento de pacientes con TDAH y dependencia de sustancias depresoras del SNC. El tratamiento habitual del TDAH se realiza con psicoestimulantes, especialmente el metilfenidato (Wilens, Morrison y Prince, 2011). Se ha planteado los posibles riesgos de mal uso y de generar adicción de estos fármacos. En este sentido, los datos provenientes de estudios realizados con animales de experimentación son contradictorios (Huss y Lehmkuhl, 2002), aunque se debe destacar que todos estos estudios se han realizado con metilfenidato intravenoso y se conoce que la vía de administración juega un papel determinante en el desarrollo de la adicción, por lo que la administración oral de metilfenidato limita su potencial de abuso (Volkow et al., 1995).

Respecto al potencial de abuso del metilfenidato, se ha observado que a pesar de que el abuso de drogas estimulantes es importante en la población juvenil, se han identificado pocos casos de abuso de metilfenidato (Babcock y Byrne, 2000; KleinSchwartz, 2002). Sin embargo, un 14\% de los adolescentes refiere haber hecho uso de la medicación con fines recreativos en alguna ocasión (Poulin, 2001). Así, el mayor riesgo de la prescripción de metilfenidato en adolescentes se refiere al potencial uso recreativo, por lo tanto, los clínicos deben vigilar a este pequeño grupo. Además, en pacientes con TUS se recomienda la utilización de estimulantes de acción prolongada, que no permitan la manipulación de las cápsula, como el metilfenidato OROS, (Schubiner, 2005), ya que el riesgo de abuso de estas presentaciones no ha sido documentado, por lo que presentan claras diferencias con el metilfenidato de liberación inmediata, con el que si existen descripciones de abuso en nuestro medio (Roncero, 2005). En estos pacientes se debe controlar aún más el uso de la medicación, limitando el número de recetas y evaluando situaciones sospechosas como "perdida" de la medicación o requerir una dosis más alta de la habitual. En estos casos las visitas continuadas y la información to the criteria of DSM-IV, so that it allows for retrospective diagnosis of ADHD in childhood in addition to adulthood. The Spanish version studied in patients with ADHD has shown good psychometric properties, with a sensitivity of $98.86 \%(95 \%$ $\mathrm{Cl}, 97.4-99.54)$ and a specificity of $67.68 \%$ (95\% Cl, 59.8874.65) and kappa index of 0.74 between the CAADID II and clinical diagnosis (Ramos-Quiroga, Bosch, Richarte, Valero, Gomez-Barros, Nogueira... Casas, 2012). Another semistructured interview is the psychiatric research interview for substance and mental disorders-IV (PRISM-IV) (Hasin, Samet, Nunes, Meydan, Matseoane y Waxman, 2006). It is a structured interview based on DSMIV-TR diagnostic criteria and is specifically designed to study comorbidity in substance use subjects. The criteria and concurrent validity of Adult ADHD section of the PRISM have been checked. The Kappa index concordance with CAADID interview was .78, sensitivity of PRISM adult ADHD module was $90 \%$ and specificity was $87.5 \%$. Authors concluded that PRISM has good psychometric properties to detect ADHD associated with SUD (RamosQuiroga, Díaz-Digon, Comín, Bosch, Palomar, Chalita, Casas, 2012).

\section{Drug treatment}

There are few studies dealing with the treatment of patients with ADHD and CNS depressant substance dependence. The standard treatment of ADHD is with psychostimulants, particularly methylphenidate (Wilens, Morrison, \& Prince, 2011). The potential risks of misuse and generating addiction to these drugs have been raised. In this regard, the data from studies in experimental animals are contradictory (Huss \& Lehmkuhl, 2002), though it should be stressed that all these studies were conducted with intravenous methylphenidate and it is known that the administration route plays a key role in the development of addiction, so oral administration of methylphenidate limits its potential for abuse (Volkow et al., 1995).

With regard to the potential for abuse of methylphenidate, it has been seen that though abuse of stimulating drugs is important in young people, few cases of methylphenidate abuse have been identified (Babcock \& Byrne, 2000; KleinSchwartz, 2002). However, 14\% of adolescents report having made use of medication for leisure purposes on some occasion (Poulin, 2001). Thus, the increased risk of prescription of methylphenidate in adolescents refers to potential recreational use; therefore, clinicians must monitor this small group. In addition, the use of long-acting stimulants that do not allow manipulation of the capsule, such as OROS methylphenidate, is recommended in patients with SUD (Schubiner, 2005), since the risk of abuse of these formulations has not been documented, so they show clear differences with immediate release methylphenidate, with which there are descriptions of abuse in our setting (Roncero, 2005). In these patients use of medication should be monitored even more, limiting the number of prescriptions and assessing suspicious situations such as "lost" medication or requiring higher than standard 
proveniente de familiares o personas cercanas al paciente cobra gran valor.

Son de interés para los clínicos los estudios los que describen que el tratamiento del TDAH con fármacos estimulantes previene el riesgo de desarrollar TUS, en hasta un 50\% (Katusic et al., 2005; Wilens, Faraone, Biederman y Gunawardene, 2003; Wilens et al., 2008).

Se ha planteado que el tratamiento de los sintomas del TDAH con estimulantes de liberación prolongada favorecería alcanzar la abstinencia prolongada con menos dificultades. Sin embargo, los resultados son controvertidos, ya que algunos estudios encuentran una reducción significativa del consumo, en muestras de 19 y 16 pacientes (Castaneda, Levy, Hardy y Trujillo, 2000; Szobot et al., 2008) y otros no, en estudios con 42 y 98 participantes (Schubiner et al., 2002; Levin et al., 2006). Debido a que, los períodos de abstinencia considerados $y$, como se ha señalado, los tamaños muestrales difieren bastante, por lo que es difícil establecer comparaciones (Levin, Evans y Kleber, 1999, Riggs, 1998; Schubiner et al., 1995; 1995; Wilens, 2004).

En dependientes de alcohol se han estudiado otras alternativas farmacológicas. En un estudio controlado con placebo sobre los efectos de la atomoxetina en adultos con TDAH dependientes de alcohol, se ha demostrado que este fármaco se asocia a una mejoría de los síntomas del TDAH, sin embargo, los datos sobre los efectos en el consumo de alcohol fueron inconsistentes (Wilens et al., 2008). Al analizar la seguridad del fármaco, se observó que los pacientes alcohólicos con TDAH no difieren en la adherencia al tratamiento de los pacientes alcohólicos sin TDAH. Al comparar los efectos adversos de la medicación, se ha encontrado que la frecuencia de efectos adversos entre pacientes que recibieron atomoxetina y placebo era comparable. Los autores concluyen que estos pacientes toleran bien el fármaco.

En cuanto a los pacientes dependientes de cannabis, existen dos estudios dirigidos a estudiar el tratamiento con metilfenidato de larga duración (Szobot y Bukstein, 2008) y con atomoxetina (McRae-Clark et al., 2010) de pacientes con TDAH. En ambos se ha concluido que el tratamiento con estos dos fármacos se asocia a una reducción de los síntomas de TDAH, pero no se asocian a una reducción del consumo de esta droga Sin embargo las muestras estudiadas son limitadas, ya que el estudio de Szobot et al. (2008), incluye 16 pacientes y el de McRae et al. 2010 incluye 19 pacientes en tratamiento farmacológico. Por ello, los resultados deben ser interpretados con precaución.

Respecto a los pacientes dependientes de opiáceos, existen dos estudios. El primero publicado fue un ensayo clínico que comparaba la prescripción de metilfenidato, bupropion y placebo en 98 pacientes en PMM. Además del tratamiento farmacológico, seguian psicoterapia cognitiva conductual. Se encontró que los tres grupos presentaban una reducción de síntomas del TDAH y no se encontraron diferencias respecto al consumo de opiáceos. El grupo placebo también se asoció a una mejoria de los síntomas comparable a los grupos tratados con metilfenidato o bupropion. No se encontraron evidencias que indiquen mal uso de la medicación o un incremento del consumo de cocaína en el grupo de pacientes tratados con metilfenidato. Los autores concluyen que el tratamiento con metilfenidato o bupropion no posee ventajas claras respecto a los síntomas de TDAH, en comparación con el pla- doses. In these cases, continued visits and information from relatives or persons close to the patient take on great value.

Of interest for clinicians are studies reporting that treatment of ADHD with stimulating drugs prevents the risk of developing SUD in up to 50\% (Katusic et al., 2005; Wilens, Faraone, Biederman, \& Gunawardene, 2003; Wilens et al., 2008).

It has been suggested that treatment of symptoms of ADHD with prolonged release stimulants would help patients to achieve prolonged abstinence with less difficulties. However, the results are controversial, as some studies found a significant reduction in use in samples of 19 and 16 patients (Castaneda, Levy, Bravo, \& Trujillo, 2000; Szobot et al., 2008) and other did not in studies with 42 and 98 participants (Schubiner et al., 2002; Levin et al., 2006). Since the periods of abstinence considered and, as noted, the sample sizes differ considerably, it is difficult to establish comparisons (Levin, Evans, \& Kleber, 1999, Riggs, 1998; Schubiner et al., 1995; 1995; Wilens, 2004).

In alcohol-dependent pateints, other drug alternatives have been studied. In a placebo-controlled study on the effects of atomoxetine in alcohol-dependent adults with ADHD, it was shown that this drug is associated with improved symptoms of $A D H D$, however, the data on the effects on alcohol use were inconsistent (Wilens et al., 2008). On analyzing drug safety, it was found that alcoholic patients with ADHD do not differ in treatment adherence from alcoholic patients without ADHD. On comparing the adverse effects of medication, have been found that the frequency of adverse effects between patients receiving atomoxetine and placebo was comparable. The authors concluded that these patients tolerated the drug well.

For cannabis-dependent patients, there are two studies aimed at investigating treatment with long-term methylphenidate (Szobot \& Bukstein, 2008) and atomoxetine (McRae-Clark et al., 2010) in patients with ADHD. Both studies concluded that treatment with these two drugs is associated with a reduction in symptoms of ADHD but not with a reduction in use of this drug. However, the samples studied are limited, since the study of Szobot et al. (2008) included 16 patients and the study of McRae et al. (2010) included 19 patients on drug treatment. Therefore, the results should be interpreted with caution.

For opioid-dependent patients, there are two studies. The first published was a clinical trial comparing prescription of methylphenidate, bupropion, and placebo in 98 patients on MMP. In addition to drug therapy, they were receiving cognitive behaviour psychotherapy. It was found that the three groups had a reduction in symptoms of ADHD and that there were no differences in opioid use. The placebo group was also associated with improved symptoms comparable to the groups treated with methylphenidate or bupropion. There was no evidence suggesting misuse of medication or increased cocaine use in the group of patients treated with methylphenidate. The authors concluded that treatment with methylphenidate or bupropion had no clear advantages over placebo with regard to symptoms of ADHD in patients on methadone maintenance treatment (Levin et al., 2006). Subsequently, a naturalistic 
cebo en pacientes en mantenimiento con metadona (Levin et al., 2006). Posteriormente, se publicó un estudio naturalístico sobre estudio los efectos del tratamiento combinado de la dependencia de opiáceos y los síntomas de TDAH. Se incluyeron 85 pacientes, describiéndose, después de 6 meses de tratamiento con mantenimiento de opiáceos y fármacos estimulantes, una reducción tanto del consumo de opiáceos como de los síntomas de TDAH (Blix, Dalteg and Nilsson, 2009). Por lo tanto la eficacia de los distintos tratamientos aún no ha sido suficientemente aclarada.

\section{Tratamiento psicosocial}

Son muy escasas las publicaciones sobre programas de intervención o guías clínicas sobre el tratamiento de pacientes con TDAH y TUS. Intervenciones psicológicas del TDAH, como la cognitivo conductual, no han sido estudiadas en drogodependientes (Safren, 2010). Goossensen et al. (2006) desarrollaron un programa de diagnóstico y tratamiento psicofarmacológico y psicosocial integral del TDAH en pacientes con TUS. La intervención psicoterapéutica o psicosocial se realizaba en un encuadre individual o grupal, dependiendo de las necesidades del paciente y la organización del centro. Incluía sesiones de psicoeducación, en que se trataban temas como información sobre síntomas de TDAH, sus consecuencias y opciones de tratamiento. Por otro lado, se incluía el entrenamiento en habilidades para favorecer la organización, planificación de actividades diarias, finanzas, competencias sociales y laborales. Además, se incluian intervenciones grupales dirigidas por un profesional, en que los pacientes podian comentar sus experiencias relacionadas con los sintomas, uso de la medicación y relaciones con los demás. A pesar de que no se realizó una evaluación formal de los resultados, los autores destacan que la experiencia fue valorada positivamente por los pacientes y profesionales involucrados en el estudio, especialmente por el carácter integrado de las intervenciones. Se necesitan estudios en que se describan y evalúen sistemáticamente intervenciones psicosociales destinadas a pacientes con esta patología dual.

\section{Conclusiones}

EI TDAH es frecuente entre pacientes con dependencia de sustancias depresoras del sistema nervioso central. La presencia del TDAH es un factor de riesgo para el desarrollo de estas adicciones. Si además del TDAH existe otra comorbilidad psiquiátrica, como el trastorno disocial o el trastorno bipolar, se favorece aún más el riesgo de abuso o dependencia de cualquier sustancia. La presencia de un TDAH modifica el curso de la adicción, aumenta el riesgo de cronicidad y de presentar más trastornos psicopatológicos y se asocia a mayor gravedad de la drogodependencia.

El grado y la fiabilidad de los conocimientos sobre la relación entre la presencia del TDAH y la adicción varian en función del tipo de droga estudiada. En este sentido, se conoce que la pre- study was published on the effects of combined treatment of opioid dependence and symptoms of ADHD. A total of 85 patients were included and after 6 months of treatment with opioid maintenance and stimulating drugs, a reduction in both opioid use and ADHD symptoms was reported (Blix, Dalteg and Selsbo, 2009). Therefore, the efficacy of the different treatments has not been sufficiently clarified.

\section{Psychosocial treatment}

There are very few publications on intervention programs or clinical guidelines on the treatment of patients with ADHD and SUD. Psychological interventions on ADHD, such as cognitive behavioral therapy, have not been studied in drug addicts (Safren, 2010). Goossensen et al. (2006) developed a integral program of diagnosis and psychopharmacological and psychosocial treatment of ADHD in patients with SUD. The psychotherapeutic or psychosocial intervention was performed on an individual or group basis, depending on the needs of the patient and site organization. It included psychoeducation sessions, where topics discussed included information on symptoms of ADHD, its consequences, and treatment options. Besides this, it included training in skills to enhance organization, planning of daily activities, finances, social and work competences. In addition, it included group interventions directed by a professional in which patients could discuss their experiences related to symptoms, use of medication and relations with others. Although a formal evaluation of results was not made, the authors stressed that the experience was positively rated by patients and professionals involved in the study, particularly for the integrated nature of interventions. Studies are required in which psychosocial interventions aimed at patients are systemically described and assessed with this dual disorder.

\section{Conclusions}

ADHD is common among patients with dependence on central nervous system depressants. The presence of ADHD is a risk factor for the development of these addictions. If, in addition to ADHD, there is another psychiatric comorbidity, such as antisocial disorder or bipolar disorder, the risk of abuse or dependence of any substance is increased even more. The presence of an ADHD modifies the course of addiction, increases the risk of chronicity and of developing more psychopathological disorders and is associated with a greater severity of drug dependence.

The degree and reliability of the knowledge on the relationship between the presence of ADHD and addiction varies depending on the type of drug studied. In this regard, it is 
sencia de un TDAH facilita la aparición de una dependencia del alcohol en la vida adulta y se asocia a mayor rapidez en la progresión de uso a dependencia. Asimismo podría estar relacionado con un inicio precoz del alcoholismo. El trastorno disocial actuaría como mediador, de la relación entre el TDAH y abuso de alcohol. En dependientes de cannabis existen pocos estudios, pero se ha señalado que es la sustancia ilegal más consumida por estos pacientes, a pesar de que su consumo aumentaría los sintomas de TDAH, fundamentalmente el déficit de atención. En dependientes de opiáceos se conoce que los pacientes con un TDAH presentan mayor gravedad de la adicción, más complicaciones psicopatológicas y tienen un peor pronóstico.

En los pacientes adictos el diagnóstico es un proceso complejo, por el posible solapamiento de los síntomas del TDAH y los asociados al consumo o abstinencia de las sustancias depresoras. Aunque existen instrumentos de cribado validados en adictos (WURS, ASRS), el diagnóstico es fundamentalmente clínico.

Aunque los algoritmos terapéuticos, no son definitivos hasta el momento, se deben tratar tanto el TDAH como la dependencia de los depresores del SNC. Existen estudios en los que se han utilizado como tratamientos farmacológicos a los psicoestimulantes, la atomoxetina y el bupropion. El tratamiento farmacológico muestra eficacia en la reducción de sintomas de TDAH en la mayoría de los estudios, no existiendo, en la actualidad, un conocimiento exacto sobe su influencia en la disminución del consumo de drogas. Aunque no existen muchas descripciones de adicción a estos fármacos, siempre debe evaluarse el riesgo de un potencial abuso, especialmente de los fármacos estimulantes de vida media corta. En estos pacientes no se ha descrito ni estudiado sistemáticamente la eficacia de las intervenciones psicoeducativas, aunque en adicciones estas intervenciones son de gran relevancia.

\section{Conflicto de intereses}

\section{Constanza Daigre no tiene conflicto de intereses.}

Carlos Roncero ha recibido honorarios por realizar charlas para Janssen-Cilag, Bristol-Mayers Squibb, Pfizer, Reckitt Benckiser, Lundbeck, Servier, GSK, Rovi y Adamed. Ha recibido compensación económica por su participación como miembro del grupo Janssen-Cilag and Shire. Ha realizado el proyecto PROTEUS que ha sido financiado por una beca otorgada por Reckitt-Benckisert.

Vicente Garcia-Vicent ha recibido compensación honoraria por realizar charlas para Janssen-Cilag, Bristol-Mayers Squibb, Pfizer, Otsuka Pharmaceuticals, Lundbeck and GSK. Ha recibido compensación económica por su participación como miembro del grupo Janssen-Cilag and Shire. Ha trabajado como investigador en el ensayo clinic llamado " A Randomized Acceptability and Safety Study of Subuxone Induction in Heroin Users" financiado por Shering-Plough.

Antonio Terán ha recibido honorarios por realizar charlas para Janssen-Cilag, Otzsuka, Pfizer, Reckitt Benckiser, Lundbeck, Servier, GSK, y Adamed. Ha recibido compensación económica por su participación como miembro del grupo Janssen-Cilag and Shire. known that the presence of a ADHD facilitates the occurrence of alcohol dependence in adulthood and is associated with a more rapid progression from use to dependence. In addition, it may be related to early onset of alcoholism. Antisocial disorder would act as a mediator of the relationship between ADHD and alcohol abuse. There are few studies in cannabis-dependent patients, but it has been reported that is the illegal substance most consumed by these patients, despite the fact that its use would increase symptoms of ADHD, mainly attention deficit. In opioid-dependent patients, it is known that patients with ADHD have more severe addiction, more psychopathological complications, and a poorer prognosis.

In addict patients, diagnosis is a complex process due to possible overlapping of symptoms of ADHD and those associated with depressant substance use or withdrawal. Although there are screening tools validated in addicts (WURS, ASRS), diagnosis is essentially clinical.

Although the therapeutic algorithms are not definitive to date, both ADHD and CNS depressant dependence should be treated. There are studies in which the psychostimulants, atomoxetine and bupropion were used as drugs treatments. Drug treatment shows efficacy in reducing the symptoms of ADHD in most studies, but currently there is no precise knowledge on its influence in the reduction of drug use. Although there are not many reports of addiction to these drugs, the risk of a potential abuse should always be assessed, particularly in the case of short half-life stimulating drugs. In these patients the efficacy of psychoeducational interventions has not been systematically described or studied, though in addictions these interventions are highly relevant.

\section{Conflicts of interest}

Constanza Daigre have not any interest conflict.

Carlos Roncero has received fees to give talks for JanssenCilag, Bristol-Mayers Squibb, Pfizer, Reckitt Benckiser, Lundbeck, Servier, GSK, Rovi and Adamed. He has received financial compensation for his participation as a member of the JanssenCilag and Shire group. He has carried out the PROTEUS project, which was funded by a grant from Reckitt-Benckisert.

Vicente Garcia-Vicent has received fees to give talks for Janssen-Cilag, Bristol-Mayers Squibb, Pfizer, Otsuka Pharmaceuticals, Lundbeck and GSK. He has received financial compensation for his participation as a member of the Janssen-Cilag and Shire group. He worked as investigator in the clinic trial called "A Randomized Acceptability and Safety Study of Subuxone Induction in Heroin Users" funded by Schering-Plough.

Antonio Terán has received fees to give talks for JanssenCilag, Otzsuka, Pfizer, Reckitt Benckiser, Lundbeck, Servier, GSK, and Adamed. He has received financial compensation for his participation as a member of the Janssen-Cilag and Shire group. 


\section{Agradecimientos}

A los integrantes del grupo CETA y sustancias depresoras: Victoria Girones, Olga Arbeo, Juan Martínez, Ma del Mar Sánchez, Paloma Sánchez, Begoña de Pablo, Emilio Rato, Silvia Piñeiro, M. Emilia García, Juan Alonso, Olga Junca, Mar Nieto, Indalecio Carrera, José Fernández, por su apoyo en el estudio del TDAH en pacientes dependientes de alcohol u opiáceos.

\section{Referencias}

Adler, L. A. (2008). Familial transmission of ADHD and psychoactive substance use disorders. The American Journal of Psychiatry, 165, 11-12. doi:10.1176/appi.ajp.2007.07101614.

Arias, A. J., Gelernter, J., Chan, G., Weiss, R. D., Brady, K. T., Farrer, L. \& Kranzler, H. R. (2008). Correlates of co-occurring ADHD in drug-dependent subjects: Prevalence and features of substance dependence and psychiatric disorders. Addictive Behaviors, 33, 1199-1207. doi:10.1016/j.addbeh.2008.05.003.

Babcock, O. \& Byrne, T. (2000). Student perceptions of methylphenidate abuse at a public liberal arts college. Journal of American College Health : J of ACH, 49, 143-145. doi:10.1080/07448480009596296.

Barkley RA. (Ed.). (1990). Attention deficit hyperactivity disorder: Handbook for diagnosis and treatment. new york, NY: Guilford press.

Barkley, R. A. (2002). Major life activity and health outcomes associated with attention-deficit/hyperactivity disorder. The Journal of Clinical Psychiatry, 63 Supp/ 12, 10-15.

Bernfort, L., Nordfeldt, S. \& Persson, J. (2008). ADHD from a socioeconomic perspective. Acta Paediatrica (Os/o, Norway:1992), 97, 239-245. doi:10.1111/j.1651-2227.2007.00611.x.

Biederman, J., Faraone, S., Milberger, S., Curtis, S., Chen, L., Marrs, A., . . Spencer, T. (1996). Predictors of persistence and remission of ADHD into adolescence: Results from a four-year prospective follow-up study. Journal of the American Academy of Child and Adolescent Psychiatry, 35, 343-351. doi:10.1097/00004583-199603000-00016.

Biederman, J., Faraone, S. V., Spencer, T., Wilens, T., Norman, D., Lapey, K. A., ... Doyle, A. (1993). Patterns of psychiatric comorbidity, cognition, and psychosocial functioning in adults with attention deficit hyperactivity disorder. The American Journal of Psychiatry, 150, 1792-1798.

Biederman, J., Wilens, T. E., Mick, E., Faraone, S. V. \& Spencer, T. (1998). Does attention-deficit hyperactivity disorder impact the developmental course of drug and alcohol abuse and dependence? Biological Psychiatry, 44, 269-273.

Bobes, J. y Calafat, A. (2010). Monografía. Cannabis. Accessed: http://www. socidrogalcohol.org/index.php?option=com docman\&task=cat_view\&gid $=27 \& \mid$ temid $=4$

Bosch, R., Ramos-Quiroga, J.A., Nogueira, M., Gómez N., Corrales, M., Palomar, G., Valero S. \& Casas, M. (2009, Mayo). Spanish validation of the Adult ADHD Rating Scale: relevance of subtypes. Póster presentado en conferencia 156 American Psychiatry Association Annual Meeting, San Francisco.

\section{Acknowledgements}

To the members of the CETA and depressant substances group: Victoria Girones, Olga Arbeo, Juan Martínez, Ma del Mar Sánchez, Paloma Sánchez, Begoña de Pablo, Emilio Rato, Silvia Piñeiro, M. Emilia García, Juan Alonso, Olga Junca, Mar Nieto, Indalecio Carrera, José Fernández, for their support in the study of ADHD in alcohol or opioid-dependent patients.

Brooner, R. K., King, V. L., Kidorf, M., Schmidt, C. W., J. \& Bigelow, G. E. (1997). Psychiatric and substance use comorbidity among treatment-seeking opioid abusers. Archives of General Psychiatry, 54, 71-80.

Carpentier, P. J., van Gogh, M. T., Knapen, L. J., Buitelaar, J. K. \& De Jong, C. A. (2010). Influence of attention deficit hyperactivity disorder and conduct disorder on opioid dependence severity and psychiatric comorbidity in chronic methadone-maintained patients. European Addiction Research, 17, 10-20. doi:10.1159/00032 1259.

Castaneda, R., Levy, R., Hardy, M. \& Trujillo, M. (2000). Long-acting stimulants for the treatment of attention-deficit disorder in cocaine-dependent adults. Psychiatric Services (Washington, D.C.), 51, 169-171.

Charach, A., Yeung, E., Climans, T. \& Lillie, E. (2011). Childhood attentiondeficit/hyperactivity disorder and future substance use disorders: Comparative meta-analyses. Journal of the American Academy of Child and Adolescent Psychiatry, 50(1), 9-21. doi:10.1016/j. jaac.2010.09.019.

Clure, C., Brady, K. T., Saladin, M. E., Johnson, D., Waid, R. \& Rittenbury, M. (1999). Attention-deficit/hyperactivity disorder and substance use: Symptom pattern and drug choice. The American Journal of Drug and Alcohol Abuse, 25(3), 441-448.

Corkum, P., Davidson, F. \& Macpherson, M. (2011). A framework for the assessment and treatment of sleep problems in children with attention-deficit/hyperactivity disorder. Pediatric Clinics of North America, 58(3), 667-683. doi:10.1016/j.pcl.2011.03.004.

Daigre, C., Ramos-Quiroga, J. A., Valero, S., Bosch, R., Roncero, C., Gonzalvo, B., Nogueira, M. \& Casas M. (2009). Adult ADHD self-report scale (ASRS-v1.1) symptom checklist in patients with substance use disorders. Actas Españolas de Psiquiatria, 37, 299-305.

Daigre, C., Roncero, C., Grau-López, L., Martínez-Luna, N., Prat, G., Valero, S., Tejedor, R., Ramos-Quiroga, J.A. \& Casas M. (In press). Attention deficit hyperactivity disorder in cocaine-dependent adults: A psychiatric comorbidity analysis. American Journal on Addiction.

Davids, E., von Bunau, U., Specka, M., Fischer, B., Scherbaum, N. \& Gastpar, M. (2005). History of attention-deficit hyperactivity disorder symptoms and opioid dependence: A controlled study. Progress in Neuro-Psychopharmacology \& Biological Psychiatry, 29, 291-296. doi:10.1016/j.pnpbp.2004.11.014

DSM III, American Psychiatric Association. (1980). Manual diagnóstico y estadístico de los trastornos mentales ( $3{ }^{\mathrm{a}} \mathrm{ed}$.).

DSM-IV-TR, Asociación Estadounidense de Psiquiatría. (2000). Manual diagnóstico y estadístico de los trastornos mentales ( 4 a ed., Texto rev.). 
Ehrenreich, H., Rinn, T., Kunert, H. J., Moeller, M. R., Poser, W., Schilling, L.,... Hoehe, M. R. (1999). Specific attentional dysfunction in adults following early start of cannabis use. Psychopharmacology, 142, 295-301.

Ercan, E. S., Coskunol, H., Varan, A. \& Toksoz, K. (2003). Childhood attention deficit/hyperactivity disorder and alcohol dependence: $A$ 1-year follow-up. Alcohol and Alcoholism (Oxford, Oxfordshire), 38, 352-356.

Faraone, S. V., Wilens, T. E., Petty, C., Antshel, K., Spencer, T. \& Biederman, J. (2007). Substance use among ADHD adults: Implications of late onset and subthreshold diagnoses. The American Journal on Addictions / American Academy of Psychiatrists in Alcoholism and Addictions, 16 Suppl 1, 24-32; quiz 33-4. doi:10.1080/10550490601082767.

Fayyad, J., De Graaf, R., Kessler, R., Alonso, J., Angermeyer, M., Demyttenaere, K., ... Jin, R. (2007). Cross-national prevalence and correlates of adult attention-deficit hyperactivity disorder. The British Journal of Psychiatry: The Journal of Mental Science, 190, 402-409.

Fergusson, D. M. \& Boden, J. M. (2008). Cannabis use and adult ADHD symptoms. Drug and Alcohol Dependence, 95, 90-96. doi:10.1016/j. drugalcdep.2007.12.012

Fischer, M., Barkley, R. A., Smallish, L. \& Fletcher, K. (2002). Young adult follow-up of hyperactive children: Self-reported psychiatric disorders, comorbidity, and the role of childhood conduct problems and teen CD. Journal of Abnormal Child Psychology, 30, 463-475.

Goksøyr, P. K. \& Nøttestad, J. A. (2008). The burden of untreated ADHD among adults: The role of stimulant medication. Addictive Behaviors, 33, 342-346.

Goossensen, M. A., van de Glind, G., Carpentier, P. J., Wijsen, R. M., van Duin, D., \& Kooij, J. J. (2006). An intervention program for ADHD in patients with substance use disorders: Preliminary results of a field trial. Journal of Substance Abuse Treatment, 30, 253-259. doi:10.1016/j.jsat.2005.12.004.

Grella, C. E., Hser, Y. I., Joshi, V. \& Rounds-Bryant, J. (2001). Drug treatment outcomes for adolescents with comorbid mental and substance use disorders. The Journal of Nervous and Mental Disease, 189, 384-392.

Hasin, D., Samet, S., Nunes, E., Meydan, J., Matseoane, K., \& Waxman, R. (2006). Diagnosis of comorbid psychiatric disorders in substance users assessed with the Psychiatric Research Interview for Substance and Mental Disorders for DSM-IV. American Journal of Psychiatry, 163, 689-696. doi:10.1176/appi.ajp.163.4.689

Harvey, M. A., Sellman, J. D., Porter, R. J. \& Frampton, C. M. (2007). The relationship between non-acute adolescent cannabis use and cognition. Drug and Alcohol Review, 26, 309-319. doi:10.1080/09595230701247772.

Harwood, H. J. \& Myers, T. G. (Eds.). (2004). New treatments for addiction: Behavioral, ethical, legal, and social questions. Washington (DC): National Academy of Sciences.

Hoban, T. F. (2004). Assessment and treatment of disturbed sleep in attention deficit hyperactivity disorder. Expert Review of Neurotherapeutics, 4, 307-316. doi:10.15 86/14737175.4.2.307.
Huss, M. \& Lehmkuhl, U. (2002). Methylphenidate and substance abuse: A review of pharmacology, animal, and clinical studies. Journal of Attention Disorders, 6 Suppl 1, S65-71.

Johann, M., Bobbe, G., Putzhammer, A. \& Wodarz, N. (2003). Comorbidity of alcohol dependence with attention-deficit hyperactivity disorder: Differences in phenotype with increased severity of the substance disorder, but not in genotype (serotonin transporter and 5-hydroxytryptamine-2c receptor). Alcoholism, Clinical and Experimental Research, 27, 1527-1534. doi:10.1097/01.ALC.000009 0143.00703.07.

Kalant, H. (2004). Adverse effects of cannabis on health: An update of the literature since 1996. Progress in Neuro-Psychopharmacology \& Biological Psychiatry, 28, 849-863. doi:10.1016/j.pnpbp.2004.05.027.

Katusic, S. K., Barbaresi, W. J., Colligan, R. C., Weaver, A. L., Leibson, C. L. \& Jacobsen, S. J. (2005). Psychostimulant treatment and risk for substance abuse among young adults with a history of attentiondeficit/hyperactivity disorder: A population-based, birth cohort study. Journal of Child and Adolescent Psychopharmacology, 15, 764-776. doi:10.1089/cap.2005.15.764.

Kessler, R. C., Chiu, W. T., Demler, O., Merikangas, K. R. \& Walters, E. E. (2005). Prevalence, severity, and comorbidity of 12-month DSM-IV disorders in the national comorbidity survey replication. Archives of General Psychiatry, 62, 617-627. doi:10.1001/archpsyc.62.6.617.

Kessler, R. C., Adler, L., Barkley, R., Biederman, J., Conners, C. K., Demler, 0.,... Zaslavsky, A. M. (2006). The prevalence and correlates of adult ADHD in the united states: Results from the national comorbidity survey replication. The American Journal of Psychiatry, 163, 716-723.

King, V. L., Brooner, R. K., Kidorf, M. S., Stoller, K. B. \& Mirsky, A. F. (1999). Attention deficit hyperactivity disorder and treatment outcome in opioid abusers entering treatment. The Journal of Nervous and Mental Disease, 187, 487-495.

Klein-Schwartz, W. (2002). Abuse and toxicity of methylphenidate. Current Opinion in Pediatrics, 14, 219-223.

Kollins, S. H. (2008). ADHD, substance use disorders, and psychostimulant treatment: Current literature and treatment guidelines. J.Atten Disord., 12, 115-125. doi:10.1177/1087054707311654.

Kolpe, M. \& Carlson, G. A. (2007). Influence of attention-deficit/ hyperactivity disorder symptoms on methadone treatment outcome. The American Journal on Addictions / American Academy of Psychiatrists in Alcoholism and Addictions, 16, 46-48. doi:10.1080/10601330601080073.

La Malfa, G., Lassi, S., Bertelli, M., Pallanti, S. \& Albertini, G. (2008). Detecting attention-deficit/hyperactivity disorder (ADHD) in adults with intellectual disability the use of conners' adult ADHD rating scales (CAARS). Research in Developmental Disabilities, 29, 158-164. doi:10.1016/j.ridd.2007.02.002.

Lee, S. S., Humphreys, K. L., Flory, K., Liu, R. \& Glass, K. (2011). Prospective association of childhood attention-deficit/hyperactivity disorder (ADHD) and substance use and abuse/dependence: A meta-analytic review. Clinical Psychology Review, 31, 328-341. doi:10.1016/j. cpr.2011.01.006.

Levin, F. R., Evans, S. M. \& Kleber, H. D. (1999). Practical guidelines for the treatment of substance abusers with adult attention-deficit 
hyperactivity disorder. Psychiatric Services (Washington, D.C.), 50, 1001-1003.

Levin, F. R., Evans, S. M., Brooks, D. J., Kalbag, A. S., Garawi, F. \& Nunes, E. V. (2006). Treatment of methadone-maintained patients with adult ADHD: Double-blind comparison of methylphenidate, bupropion and placebo. Drug and Alcohol Dependence, 81, 137-148.

Lundqvist, T. (2005). Cognitive consequences of cannabis use: Comparison with abuse of stimulants and heroin with regard to attention, memory and executive functions. Pharmacology, Biochemistry, and Behavior, 81, 319-330. doi:10.1016/j. pbb.2005.02.017.

McRae-Clark, A. L., Carter, R. E., Killeen, T. K., Carpenter, M. J., White, K. G. \& Brady, K. T. (2010). A placebo-controlled trial of atomoxetine in marijuana-dependent individuals with attention deficit hyperactivity disorder. The American Journal on Addictions / American Academy of Psychiatrists in Alcoholism and Addictions, 19, 481-489. doi:10.1111/j.1521-0391.2010.00076.x.

Modestin, J., Matutat, B. \& Wurmle, 0. (2001). Antecedents of opioid dependence and personality disorder: Attention-deficit/ hyperactivity disorder and conduct disorder. European Archives of Psychiatry and Clinical Neuroscience, 251, 42-47.

Ohlmeier, M. D., Peters, K., Kordon, A., Seifert, J., Wildt, B. T., Wiese, B., ... Schneider, U. (2007). Nicotine and alcohol dependence in patients with comorbid attention-deficit/hyperactivity disorder (ADHD). Alcohol and Alcoholism (Oxford, Oxfordshire), 42, 539-543. doi:10.1093/alcalc/agm069.

Ohlmeier, M. D., Peters, K., Te Wildt, B. T., Zedler, M., Ziegenbein, M., Wiese, B., .. Schneider, U. (2008). Comorbidity of alcohol and substance dependence with attention-deficit/hyperactivity disorder (ADHD). Alcohol and Alcoholism (Oxford, Oxfordshire), 43, 300-304. doi:10.1093/alcalc/agn014.

Blix, O., Dalteg A. \& Nilsson, P. (2009). Treatment of opioid dependence and ADHD/ADD with opioid maintenance and central stimulants. Heroin addict relat clin probl 2009; 11: 5-14.

Pedrero Perez, E. J. \& Puerta Garcia, C. (2007). ASRS v.1.1., a tool for attention-deficit/hyperactivity disorder screening in adults treated for addictive behaviors: Psychometric properties and estimated prevalence. Adicciones, 19, 393-407.

Perez de Los Cobos, J., Sinol, N., Puerta, C., Cantillano, V., Lopez Zurita, C. \& Trujols, J. (2010). Features and prevalence of patients with probable adult attention deficit hyperactivity disorder who request treatment for cocaine use disorders. Psychiatry Research, 30,20510. doi:10.1016/j.psychres.2009.03.019.

Poulin, C. (2001). Medical and nonmedical stimulant use among adolescents: From sanctioned to unsanctioned use. CMAJ:Canadian Medical Association Journal = Journal De L'Association Medicale Canadienne, 165, 1039-1044.

Plan Nacional Sobre Drogas (2009). Memoria. Ministerio de Sanidad, Politica Social e Igualdad. Accessed

http://www.pnsd.msc.es/Categoria2/publica/publicaciones/home.htm accedido el 2 enero 2012.

Ramos-Quiroga, J. A., Diaz-Digon, L., Comin, M., Bosch, R., Palomar, G., Chalita, J. P., Roncero C, Nogueira M, Torrens M, Casas
M. (2012). Criteria and concurrent validity of adult ADHD section of the psychiatry research interview for substance and mental disorders. Journal of Attention Disorders22, 1-8. doi:, 10.1177/1087054712454191

Ramos-Quiroga, J. A., Bosch, R., Richarte, V., Valero, S., Gomez-Barros, N., Nogueira, M., ... Casas, M. (2012). Criterion and concurrent validity of conners adult ADHD diagnostic interview for DSM-IV (CAADID) spanish version. Revista De Psiquiatria y Salud Mental, 5(4), 229235. doi: 10.1016/j.rpsm.2012.05.004; 10.1016/j.rpsm.2012.05.004

Riggs, P. D. (1998). Clinical approach to treatment of ADHD in adolescents with substance use disorders and conduct disorder. Journal of the American Academy of Child and Adolescent Psychiatry, 37, 331-332.

Rodriguez-Jimenez, R., Ponce, G., Monasor, R., Jimenez-Gimenez, M., Perez-Rojo, J. A., Rubio, G., ... Palomo, T. (2001). Validation in the adult spanish population of the wender utah rating scale for the retrospective evaluation in adults of attention deficit/hyperactivity disorder in childhood. Revista De Neurologia, 33, 138-144.

Roncero, C. (2005). Abuso de metilfenidato y TOC. en Alvarez, E. y Gándara J. (eds.), En el día a día de la psiquiatría.(pp. 21-24). Madrid: SPA.

Roncero C, Fuste G, Barral C, Rodríguez-Cintas L, Martínez-Luna $N$, Eiroa-Orosa FE, Casas M, on behalf of the PROTEUS study investigators (2011). Therapeutic management and comorbidities in opiate-dependent patients undergoing a replacement therapy programme in Spain: the PROTEUS study. Heroin Add \& Relat Clin Probl; 13: 5-16

Safren, S.A., sprich, S., mimiaga, M.J., surman, C., knouse, L., groves, M., otto, M.W. (2010). Cognitive-behavioral therapy vs relaxation with educational support for medication-treated adults with ADHD and persistent symptoms. J. am. med. assoc. 304, 875-880.

Tims, F. M., Dennis, M. L., Hamilton, N., J Buchan, B., Diamond, G., Funk, R. \& Brantley, L. B. (2002). Characteristics and problems of 600 adolescent cannabis abusers in outpatient treatment. Addiction (Abingdon, England), 97 Suppl 1, 46-57.

Kooij, S., Boonstra, M.A., Swinkels, S. H., Bekker, E. M., de Noord, I. \& Buitelaar, J. K. (2008). Reliability, validity, and utility of instruments for self-report and informant report concerning symptoms of ADHD in adult patients. Journal of Attention Disorders, 11, 445-458. doi:10.1177/1087054707299367.

Sartor, C. E., Lynskey, M. T., Heath, A. C., Jacob, T. \& True, W. (2007). The role of childhood risk factors in initiation of alcohol use and progression to alcohol dependence. Addiction (Abingdon, England), 102, 216-225. doi:10.1111/j.1360-0443.2006.01661.x.

Schubiner, H. (2005). Substance abuse in patients with attention-deficit hyperactivity disorder: Therapeutic implications. CNS Drugs, 19, 643-655.

Schubiner, H., Saules, K. K., Arfken, C. L., Johanson, C. E., Schuster, C. R., Lockhart, N., ... Pihlgren, E. (2002). Double-blind placebo-controlled trial of methylphenidate in the treatment of adult ADHD patients with comorbid cocaine dependence. Experimental and Clinical Psychopharmacology, 10, 286-294.

Schubiner, H., Tzelepis, A., Isaacson, J. H., Warbasse, L. H.,3rd, Zacharek, M. \& Musial, J. (1995). The dual diagnosis of attention-deficit/ 
hyperactivity disorder and substance abuse: Case reports and literature review. The Journal of Clinical Psychiatry, 56, 146-150.

Solowij, N., Stephens, R. S., Roffman, R. A., Babor, T., Kadden, R., Miller, M., ... Marijuana Treatment Project Research Group. (2002). Cognitive functioning of long-term heavy cannabis users seeking treatment. JAMA : The Journal of the American Medical Association, 287, 1123-1131.

Sringeri, S. K., Rajkumar, R. P., Muralidharan, K., Chandrashekar, C. R. \& Benegal, V. (2008). The association between attention-deficit/ hyperactivity disorder and early-onset alcohol dependence: A retrospective study. Indian Journal of Psychiatry, 50, 262-265. doi:10.4103/0019-5545.44748

Subramaniam, G. A. \& Stitzer, M. A. (2009). Clinical characteristics of treatment-seeking prescription opioid vs. heroin-using adolescents with opioid use disorder. Drug and A/cohol Dependence, 101, 13-19. doi:10.1016/j.drugalcdep.2008.10.015.

Sullivan, M. A. \& Rudnik-Levin, F. (2001). Attention deficit/hyperactivity disorder and substance abuse. diagnostic and therapeutic considerations. Annals of the New York Academy of Sciences, 931, 251-270.

Szobot, C. M. \& Bukstein, 0. (2008). Attention deficit hyperactivity disorder and substance use disorders. Child and Adolescent Psychiatric Clinics of North America, 17, 309-323. doi:10.1016/j. chc.2007.11.003.

Szobot, C. M., Rohde, L. A., Katz, B., Ruaro, P., Schaefer, T., Walcher, M., ... Pechansky, F. (2008). A randomized crossover clinical study showing that methylphenidate-SODAS improves attention-deficit/ hyperactivity disorder symptoms in adolescents with substance use disorder. Brazilian Journal of Medical and Biological Research

Tuithof, M., Ten Have, M., van den Brink, W., Vollebergh, W. \& de Graaf, R. (2011). The role of conduct disorder in the association between ADHD and alcohol use (disorder). results from the netherlands mental health survey and incidence study-2. Drug and Alcohol Dependence, 123, 15-21. doi:10.1016/j.drugalcdep.2011.10.030.

van Emmerik-van Oortmerssen, K., van de Glind, G., van den Brink, W., Smit, F., Crunelle, C. L., Swets, M. \& Schoevers, R. A. (2011). Prevalence of attention-deficit hyperactivity disorder in substance use disorder patients: A meta-analysis and meta-regression analysis. Drug and Alcohol Dependence, 122, 11-19. doi:10.1016/j.drugalcdep.2011.12.007

Volkow, N. D., Ding, Y. S., Fowler, J. S., Wang, G. J., Logan, J., Gatley, J. S., ... Hitzemann, R. (1995). Is methylphenidate like cocaine? studies on their pharmacokinetics and distribution in the human brain. Archives of General Psychiatry, 52, 456-463.

Vergara-Moragues, E., González-Saiz, F., Lozano-Rojas, O., Bilbao-Acedos, I., Fernández-Calderón F., Betanzos-Espinosa, P., Verdejo-García A. \& Pérez-Garcia M. (2010). Diagnóstico del trastorno por déficit de atención e hiperactividad (TDAH) en pacientes adultos con dependencia de cocaina: utilidad de los nuevos sintomas de funcionamiento ejecutivo de Barkley. Trastornos Adictivos, 12, 72-78.

Wilens, T. E. (2004). Attention-deficit/hyperactivity disorder and the substance use disorders: The nature of the relationship, subtypes at risk, and treatment issues. The Psychiatric Clinics of North America, 27, 283-301. doi:10.1016/S0193-953X(03)00113-8.
Wilens, T. E., Adamson, J., Monuteaux, M. C., Faraone, S. V., Schillinger, M., Westerberg, D. \& Biederman, J. (2008). Effect of prior stimulant treatment for attention-deficit/hyperactivity disorder on subsequent risk for cigarette smoking and alcohol and drug use disorders in adolescents. Archives of Pediatrics \& Adolescent Medicine, 162, 916-921. doi:10.1001/archpedi.162.10.916.

Wilens, T. E., Adler, L. A., Weiss, M. D., Michelson, D., Ramsey, J. L., Moore, R. J., ... Atomoxetine ADHD/SUD Study Group. (2008). Atomoxetine treatment of adults with ADHD and comorbid alcohol use disorders. Drug and Alcohol Dependence, 96, 145-154. doi:10.1016/j. drugalcdep.2008.02.009.

Wilens, T. E., Biederman, J. \& Mick, E. (1998). Does ADHD affect the course of substance abuse? findings from a sample of adults with and without ADHD. The American Journal on Addictions / American Academy of Psychiatrists in Alcoholism and Addictions, 7, 156-163.

Wilens, T. E., Biederman, J. Mick, E., Faraone, S. V. \& Spencer, T. (1997). Attention deficit hyperactivity disorder (ADHD) is associated with early onset substance use disorders. The Journal of Nervous and Mental Disease, 185, 475-482.

Wilens, T. E., Faraone, S. V., Biederman, J., \& Gunawardene, S. (2003). Does stimulant therapy of attention-deficit/hyperactivity disorder beget later substance abuse? A meta-analytic review of the literature. Pediatrics, 111, 179-185.

Wilens, T. E., Morrison, N. R. \& Prince, J. (2011). An update on the pharmacotherapy of attention-deficit/hyperactivity disorder in adults. Expert Review of Neurotherapeutics, 11, 1443-1465. doi:10.1586/ern.11.137.

Wilens, T. E. \& Dodson, W. (2004). A clinical perspective of attentiondeficit/hyperactivity disorder into adulthood. The Journal of Clinical Psychiatry, 65, 1301-1313. 